\title{
Identification of aberrant white matter bundles entering the inferior cerebellar peduncle
}

Figure 1 Gross appearance of aberrant white matter bundles
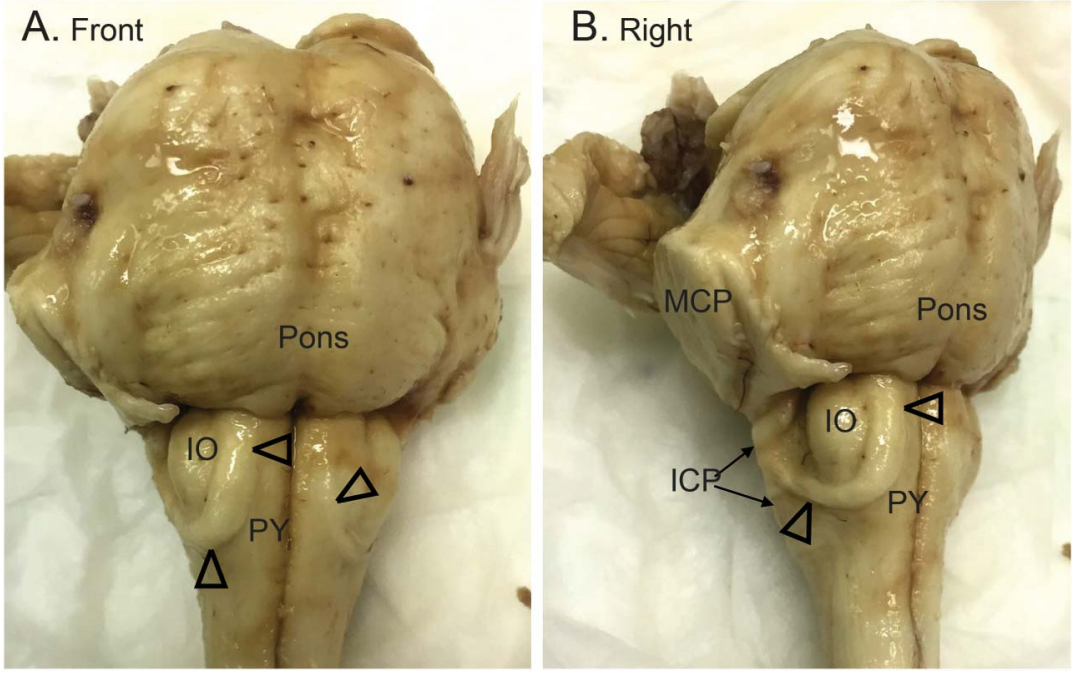

Bilateral, aberrant white matter bundles (arrowheads) are observed leaving the pyramidal tract (PY), circumscribing the inferior olive (IO), and entering the inferior cerebellar peduncle (ICP; middle cerebellar peduncle [MCP]). The aberrant bundles are markedly smaller on the left side of the brainstem.

Figure 2 Histologic appearance of aberrant white matter bundles in the medulla

A. Rostral

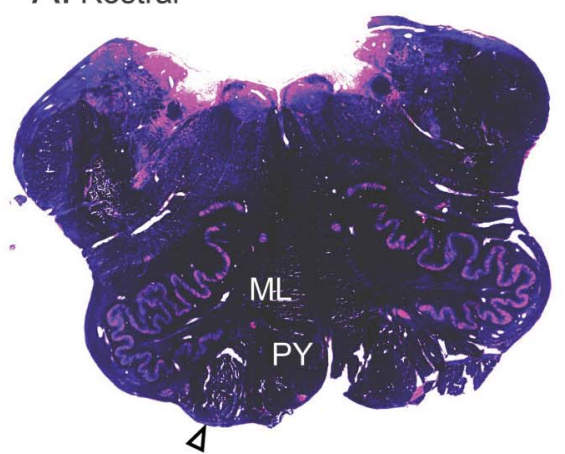

B. Caudal

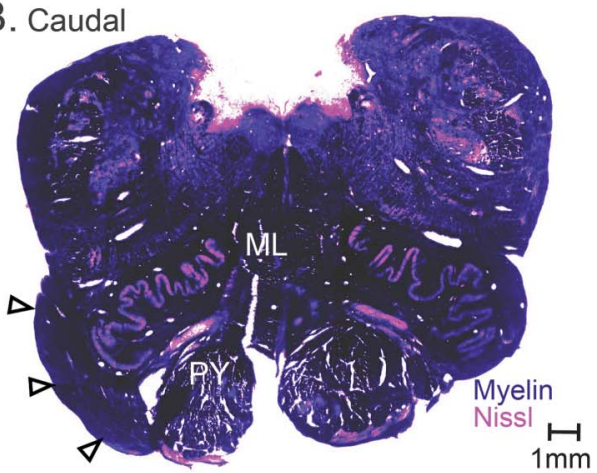

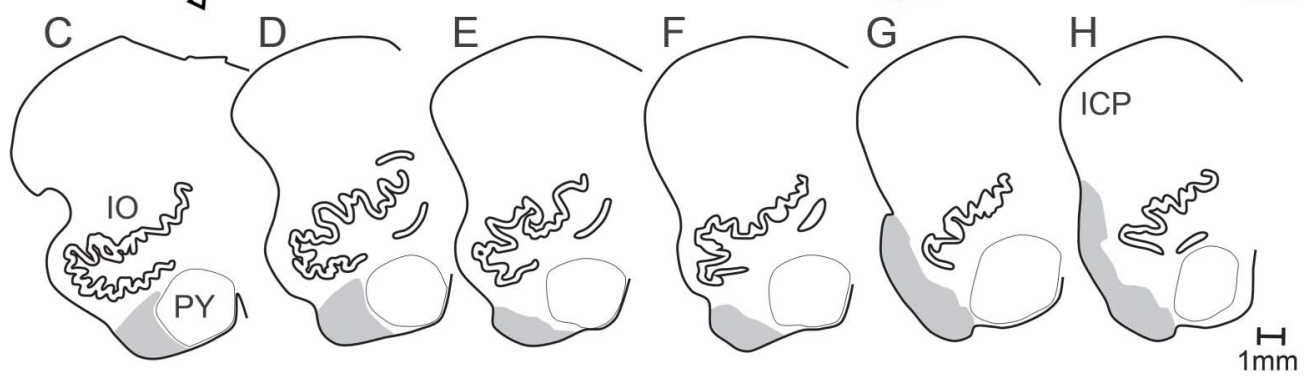

Aberrant white matter bundles (arrowheads in A and B; gray contours in $\mathrm{C}-\mathrm{H}$ ) could be traced in sections from the medulla, where they separate from the pyramidal tracts $(P Y)$ in the rostral medulla $(M L)(A)$, course external to the caudal inferior olive (IO) (B), and enter the inferior cerebellar peduncle (ICP). 
During postmortem examination of a 34-year-old man with accidental death and no prior neurologic dysfunction, bilateral aberrant axon bundles were identified in the brainstem (figure 1). These bundles left the pyramidal tract in the medulla, passed caudally around the inferior olive, and entered the inferior cerebellar peduncle. In sections through the pons, these bundles projected towards pontine nuclei. In the medulla, these bundles were distinct from the pyramidal tract (figure 2). This bundle is termed fascicularis circumolivaris pyramidalis ${ }^{1}$ and appears to be aberrant pontocerebellar axons. ${ }^{2}$ This extremely rare variation might be mistaken for hypertrophic olivary degeneration or brainstem glioma.

Kaitlyn Blackburn, Jennifer LeMay, Gary Dale, MD, Lilian Calderón-Garcidueñas, MA, MD, PhD, Randy Kulesza, Jr., PhD

From Lake Erie College of Osteopathic Medicine (K.B., J.L., R.K.), Erie, PA; forensic pathology consultant (G.D.); and University of Montana (L.C.-G.), Missoula.

Author contributions: Kaitlyn Blackburn: manuscript design, processed tissue, wrote and revised manuscript, constructed figures. Jennifer LeMay: manuscript design, processed tissue, wrote and revised manuscript, constructed figures. Gary Dale: performed autopsy, revised manuscript. Lilian Calderón-Garcidueñas: manuscript concept and design, wrote and revised manuscript. Randy Kulesza Jr.: manuscript concept and design, wrote and revised manuscript, constructed figures.

Acknowledgment: The authors thank the Lake Erie College of Osteopathic Medicine Research Consortium.

Study funding: No targeted funding reported.

Disclosure: The authors report no disclosures relevant to the manuscript. Go to Neurology.org for full disclosures.

Correspondence to Dr. Kulesza: rkulesza@lecom.edu

1. Robinson A, editor. Cunningham's Textbook of Anatomy, 4th ed. New York: William Wood and Company; 1913.

2. Raymond T, Carpenter M. Human Neuroanatomy, Gth ed. Baltimore: Williams \& Wilkins; 1969.

\section{Subspecialty Alerts by E-mail!}

Customize your online journal experience by signing up for e-mail alerts related to your subspecialty or area of interest. Access this free service by visiting Neurology.org/site/subscriptions/etoc.xhtml or click on the "E-mail Alerts" link on the home page. An extensive list of subspecialties, methods, and study design choices will be available for you to choose from—allowing you priority alerts to cutting-edge research in your field!

\section{Minutes Pack a Punch}

\section{Neurology ${ }^{\circledR}$ Podcasts}

- Interviews with top experts on new clinical research in neurology

- Editorial comments on selected articles

- Convenient-listen during your commute, at your desk, or even at the gym

- On demand-it's there when you want it

- Fun and engaging

- New topic each week

- FREE

Listen now at www.aan.com/podcast 


\section{Neurology}

\section{Identification of aberrant white matter bundles entering the inferior cerebellar peduncle}

Kaitlyn Blackburn, Jennifer LeMay, Gary Dale, et al. Neurology 2017;88;106-107

DOI 10.1212/WNL.0000000000003463

This information is current as of December 26, 2016

$\begin{array}{ll}\begin{array}{l}\text { Updated Information \& } \\ \text { Services }\end{array} & \begin{array}{l}\text { including high resolution figures, can be found at: } \\ \text { http://n.neurology.org/content/88/1/106.full }\end{array} \\ \text { Subspecialty Collections } & \begin{array}{l}\text { This article, along with others on similar topics, appears in the } \\ \text { following collection(s): } \\ \text { All Clinical Neurology } \\ \text { http://n.neurology.org/cgi/collection/all_clinical_neurology } \\ \text { All Education } \\ \text { http://n.neurology.org/cgi/collection/all_education }\end{array} \\ & \begin{array}{l}\text { Information about reproducing this article in parts (figures,tables) or in } \\ \text { its entirety can be found online at: } \\ \text { http://www.neurology.org/about/about_the_journal\#permissions } \\ \text { Permissions \& Licensing } \\ \text { Information about ordering reprints can be found online: } \\ \text { http://n.neurology.org/subscribers/advertise }\end{array} \\ \text { Reprints } & \end{array}$

Neurology ${ }^{\circledR}$ is the official journal of the American Academy of Neurology. Published continuously since 1951, it is now a weekly with 48 issues per year. Copyright () 2016 American Academy of Neurology. All rights reserved. Print ISSN: 0028-3878. Online ISSN: 1526-632X.

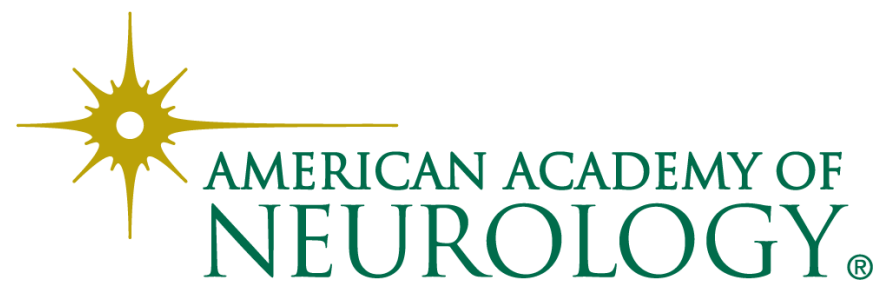

